\title{
PERANCANGAN APLIKASI MANAGEMENT TASK PADA PT.ENKA ANUGRAH INDONESIA DI KOTA TANGERANG
}

\author{
Sudrajat $^{1}$, Rudi Hermawan ${ }^{2}$, Sutrisno ${ }^{3}$ \\ 1,2,3 Universitas Indraprasta PGRI \\ Jl. Raya Tengah No. 80, Kel. Gedong, Kec. Pasar Rebo, Jakarta Timur 13760 \\ ${ }^{1}$ ajat91.sudrajat@gmail.com ${ }^{2}$ rh001unindra@gmail.com ${ }^{3}$ sutrisno3831@gmail.com
}

\begin{abstract}
ABSTRAK
PT. Enka Anugrah Indonesia bergerak di bidang teknologi, khususnya dalam pembuatan aplikasi. Setiap aplikasi yang sedang dikerjakan akan dibuat bisnis proses dari aplikasi tersebut, kemudian dipecah menjadi beberapa Task. Task yang dibuat didistribusikan kepada karyawan yang ditugaskan melalui email. Pendistribusian Task melalui email sudah sangat membantu dalam melakukan pekerjaan, akan tetapi leader project sulit untuk mengontrol atau mengetahui progress dari Task yang dikerjakan. Tujuan dari penelitian ini adalah untuk mempermudah pendistribusian atau mengontrol progress pekerjaan yang ditugaskan kepada karyawan dengan efektif dan efisien. Metodologi yang digunakan adalah metode observasi, metode wawancara, metode pustaka, serta studi literature sejenis. Metode pengembangan sistem yang digunakan adalah waterfall. Aplikasi ini dibuat menggunakan Netbeans, bahasa pemograman java dan mysql, Untuk menggambarkan algoritma yang terstruktur dan mudah dipahami peneliti menggunakan Unified Modelling Language (UML) sebagai alat bantu. Hasil dari penelitian ini adalah terancangnya aplikasi management task yang dapat mempermudah dan mempercepat leader project mengontrol progress tugas yang sedang dikerjakan oleh karyawan dan mempermudah dalam membuat rekap atau laporan pekerjaan yang telah diselesaikan dalam satu periode.
\end{abstract}

Kata Kunci: Java Netbeans, Task Management, Support

\begin{abstract}
PT. Enka Anugrah Indonesia is engaged in technology, especially in application development. Each application will be made a business process from the application, then broken down into several tasks. Tasks created are distributed to assigned employees via email. Task distribution via email has been beneficial in doing the work, but the project leader is difficult to control or know the progress of the task. This research aims to facilitate the distribution or control of the progress of work assigned to employees effectively and efficiently. The methodology used is the observation method, interview method, library method, and similar literature studies. The system development method used is the waterfall. This application is using Netbeans, Java, and MySQL programming languages. To describe a structured and easy-to-understand algorithm, the researcher uses the Unified Modeling Language (UML) as a tool. The results of this study are the design of a task management application that can simplify and speed up project leaders controlling the progress of tasks being carried out by employees and making it easier to make recaps or reports of work that completed in one period.
\end{abstract}

Key Word: Java Netbeans, Task Management, Support

\section{PENDAHULUAN}

Dewasa ini perkembangan dunia teknologi sudah tidak bisa dibendung lagi. Terlebih sudah masuk era industri 4.0 yang menggunakan teknologi sebagai dasar dalam proses transaksi dan pembuatan suatu produk. Pada dewasa ini, hampir sepenuhnya bergantung pada internet seperti hubungan antar manusia yang bisa terjadi dengan adanya media sosial, belanja secara online, belajar mengajarpun bisa dilakukan dengan gadget, dan lain-lain.

Semakin meleknya manusia dengan teknologi dan menyadari banyak hal positif yang bisa didapat terutama bagi suatu industri membuat banyak perusahaan merubah proses transaksi dari cara tradisional menjadi modern dengan menggunakan teknologi. Begitu pun yang diterjadi pada PT. Enka Anugrah Indonesia dalam menangani pembagian tugas kerja oleh leader project kepada karyawan nya.

Sebelumnya, Task yang telah ditentukan akan di berikan kepada karyawan yang ditugaskan melalui email. Pendistribusian Task melalui email sudah sangat membantu dalam melakukan pekerjaan, akan tetapi leader project sulit untuk mengontrol atau mengetahui progress dari Task yang sedang dilakukan oleh karyawan secara realtime. Sehingga leader 
project harus menanyakan kepada karyawan yang mengerjakan task tersebut melalui chatting atau bertanya secara langsung, dimana cara ini tidak efektif dalam mengontrol pekerjaan karena respon yang terkadang lambat.

Karena ketidak efektifan tersebut, perusahaan membutuhkan suatu aplikasi untuk mempermudah leader project dan pimpinan perusahaan dalam mendistribusikan tugas kerja atau Task dan mengontrol progress dalam penyelesaian Task yang diterima masingmasing karyawan. Sehingga penulis tertarik untuk membuat penelitian dengan judul "Perancangan Aplikasi Management Task Pada PT. Enka Anugrah Indonesia Di Kota Tangerang".

Pada penelitian sebelumnya mengenai Implementasi penerapan sistem manajemen tugas dan evaluasi jabatan (KPI) di PT.Intisoft Mitra Sejahtera, sistem ini menerapkan metode model waterfall. Aplikasi ini digunakan untuk tugas-tugas manajemen dan evaluasi pekerjaan, dapat membantu memantau dan mencatat masalah-masalah di perusahaan dan mengevaluasi kinerja karyawan dalam menangani laporan masalah yang dilaporkan oleh pelanggan. (Zega, Chandrika, Siswanto, \& Supardinah, 2018).

Penelitian serupa yang membahas Pembangunan Aplikasi manajemen tugas yang menggunakan PHP dan Mysql untuk mendukung proyek pengembangan perangkat lunak (studi kasus: PT.eBdeskIndonesia). Dirancang dan dibangun menggunakan bahasa pemrograman PHP dan database MySQL, aplikasi ini memfasilitasi proses perencanaan dan konfigurasi di tempat kerja dan memfasilitasi tugas tugas oleh pemimpin dan karyawan. Dibuat dengan PT eBdesk Teknologi. Selain itu, aplikasi ini membantu menetapkan jadwal harian untuk memperjelas tugas yang harus dilakukan oleh para pemimpin dan bawahannya setiap hari. (Fauzan \& Nugraha, 2017).

Desain dalam pengembangan perangkat lunak adalah upaya untuk membangun sistem yang memenuhi (mungkin secara informal) spesifikasi persyaratan fungsional, memenuhi tujuan, secara implisit atau eksplisit memenuhi persyaratan dalam hal kinerja dan penggunaan sumber daya, dan memenuhi kendala proses desain dalam hal biaya, waktu, dan peralatan. (A. S \& Shalahuddin, 2018).

Aplikasi adalah sekumpulan perintah program yang dibuat untuk memungkinkan pengguna melakukan tugas manajemen informasi tertentu dengan mudah dan menghasilkan keluaran yang disesuaikan dengan kebutuhan. (Bahrudin, Ridwan, \& Darmojo, 2019).Aplikasi adalah program yang dapat digunakan oleh pengguna aplikasi itu sendiri untuk melakukan banyak perintah. (Karnovi, 2020, p. 14).

Manajemen adalah suatu kegiatan yang direncanakan, dilaksanakan, dipantau dan dikendalikan dalam upaya menuju tujuan tertentu yang dicapai melalui pemanfaatan sumber daya manusia dan sumber daya lainnya(Robby Saepul, 2019, p. 3).Task adalah merupakan aktivitas atau tujuan/sasaran yang diterapkan dalam penggunaan bahasa seperti mencari solusi atau memecahkan teka-teki. Sementara pengertian dari Management Task sendiri adalah aktivitas di mana seorang individu atau pemimpin tim melacak sebuah tugas sepanjang siklus hidup yang menciptakan sebuah keputusan yang didasari oleh kemajuan sistem itu sendiri.(Ahmad Subhan Roza, 2015, p. 358).

Netbeans merupakan aplikasi Integrated Development Environment atau disingkat (IDE) yang basis bahasa pemograman Java dibawah naungan Sun Microsystem yang beroperasi pada swing yang saat ini banyak digunakan sebagai editor untuk macam-macam bahasa pemrograman. (Nofriandi, 2018, p. 4).

Database (basis data) secara harfiah dapat diartikan sebagai kumpul dari berbagai macam data. Data tersebut dapat berupa text, gambar, suara, video dan berbagai multimedia lainnya. Secara khusus, Database dapat di artikan pula kumpulan dari berbagai macam Object data yang termasuk di dalamnya kumpulan. (Aryanto, 2018, p. 17).

Untuk menggambarkan algoritma terstruktur yang dapat dimengerti orang lain (terutama programmer yang mengerjakan dan mengimplementasikan program) dapat dengan mudah memahami, maka diperlukan alat bentuk Unified Modelling Language atau disingkat (UML). Unified Modeling Language (UML) 
merupakan bahasa spesifikasi standar yang digunakan untuk mendokumentasikan, menentukan, dan membuat perangkat lunak.(Hendini, 2016)

Secara umum tujuan dilakukannya penelitian ini ialah untuk membantu proses penugasan dari leader project kepada karyawan PT. Enka Anugrah Indonesia agar tersampaikan dengan baik dengan merubah proses pelaporan yang sebelumnya menggunakan email atau whatsapp group ke dalam bentuk aplikasi.

Tujuan dari penelitian ini adalah dapat memudahkan manajemen dalam masalah penugasan dan memudahkan manajemen dalam pembuatan laporan, serta dapat mengetahui progress kerja dari setiap karyawan.

\section{METODE PENELITIAN}

Penelitian ini dilakukan di PT. Enka Anugrah Indonesia yang berlokasi di tangerang dengan alokasi waktu mulai dari minggu ke-4 bulan Maret hingga akhir Juni 2020. Aktifitas yang dilakukan selama penelitian adalah pengumpulan data, analisa permasalahan, merancang aplikasi, membuat aplikasi, dan melakukan pengujian.

Pada tahap pengumpulan data, penulis menggunakan observasi, wawancara, pustaka dan literatur sebagai metode nya.

\section{Metode Observasi}

Observasi adalah metode pengumpulan data dengan mengamati secara langsung. Dalam metode ini peneliti melakukan observasi atau investigasi langsung dengan PT. Enka Angrah Indonesia untuk mendapatkan informasi yang benar-benar akurat. Selain itu, metode ini juga digunakan untuk menambah informasi tentang aktivitas yang berkaitan dengan masalah yang terjadi.

\section{Metode Wawancara}

Metode wawancara digunakan untuk pengumpulan data dengan cara mengajukan berbagai pertanyaan kepada perusahaan. Pertanyaan yang diajukan berhubungan dengan proses penugasan dari leader project dan hal apa saja yang dibutuhkan perusahaan terhadap aplikasi management task.

\section{Metode Pustaka}

Metode pustaka merupakan metode dengan mempelajari buku-buku yang berhubungan langsung dengan masalah yang dibahas. Selain itu, peneliti juga mencari informasi di internet terkait topik yang sedang berkembang.

\section{Studi Literatur Sejenis}

Metode ini merupakan metode penelitian dan pengumpulan data pada penelitian sejenis melalui sistem management task. Cara ini akan membantu Anda lebih memahami solusi dari masalah yang dihadapi. Juga, dengan cara ini, aplikasi management task.

Desain penelitian merupakan tahapan yang dilakukan sebelum penelitian. Dalam penelitian ini desain yang digunakan ialah desain waterfall model. Model waterfall menggambarkan sebuah siklus perangkat lunak secara sekuansial atau terstruktur dimulai dari perencanaan, pendesainan, pemrosesan, proses uji, dan tahap pengembangannya.(A. S \& Shalahuddin, 2018).

Pengembangan sistem pada aplikasi management task menggunakan beberapa metode yang berdasarkan pada model waterfall. Berikut ini metode pengembangan sistem model waterfall pada aplikasi management task.

\section{Analisa Perancangan Perangkat Lunak}

Pada tahap awal, peneliti melakukan analisa pada data yang telah dikumpulkan seperti data laporan. Selain itu, peneliti juga melakukan wawancara dan observasi terhadap kegiatan yang ada di perusahaan ini guna membantu proses analisis yang peneliti lakukan.

\section{Desain}

Pada tahapan ini, peneliti mulai merancang proses aplikasi baru menggunakan Unified Modeling Language (UML) untuk pemodelan. Selain itu, peneliti juga merancang database dan layout layar untuk memudahkan pembuatan aplikasi ini.

\section{Pengodean}

Pada pembuatan aplikasi penulis menggunakan Java Netbeans IDE dengan bahasa Java untuk pengodeannya dan MySQL sebagai databasenya.

\section{Pengujian}

Setelah proses pengodean selesai, tahap selanjutnya adalah melakukan pengujian (testing) pada aplikasi yang dibuat. Pengujian (testing) lebih difokuskan pada aplikasi dari 
segi fungsional serta memastikan bahwa semua bagian dari aplikasi sudah diuji dan siap untuk digunakan. Pengujian dilakukan untuk meminimalkan kesalahan dan memastikan bahwa keluaran yang dihasilkan sesuai dengan yang diharapkan.

\section{HASIL DAN PEMBAHASAN}

Perancangan Use case.

Use case atau diagram use case adalah model dari perilaku (behavior) dari suatu sistem informasi yang sedang diimplementasikan. Use case menggambarkan interaksi antara sistem informasi yang dihasilkan dari satu atau lebih aktor. Use case sering digunakan untuk mengetahui apa saja fitur sistem informasi dan siapa yang memiliki izin untuk menggunakan fitur tersebut.

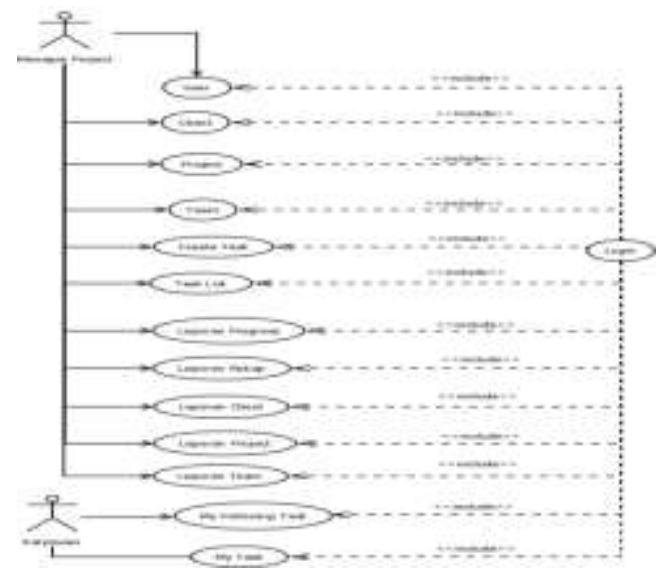

Gambar 1. Use Case Diagram

\section{Perancangan Class Diagram}

Class diagram mendeskripsikan struktur sistem berdasarkan segi pendefinisian kelas-kelas yang akan dibentuk untuk menciptakan sistem. Kelas mempunyai apa yang dianggap atribut dan method atau operasi.

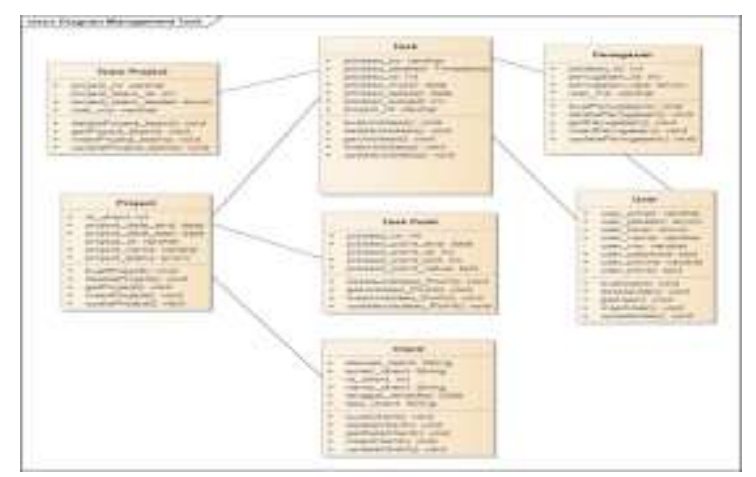

Gambar 2. Class Diagram
Tampilan Aplikasi

Untuk masuk ke dalam aplikasi user harus mengisi nip dan password yang telah didaftarkan di dalam database.

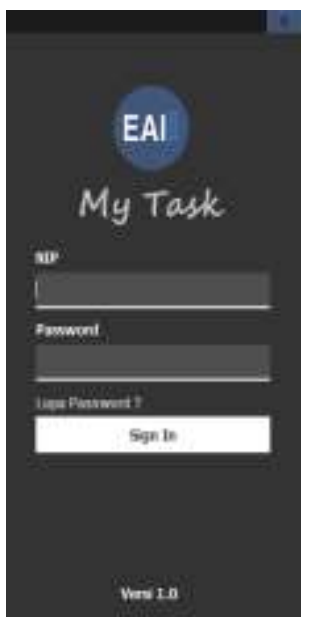

Gambar 3. Tampilan Login

Jika login berhasil maka akan masuk kedalam menu utama. Pada menu dibawah ini ada beberapa item menu yaitu user, client, project, team project dan lainnya.
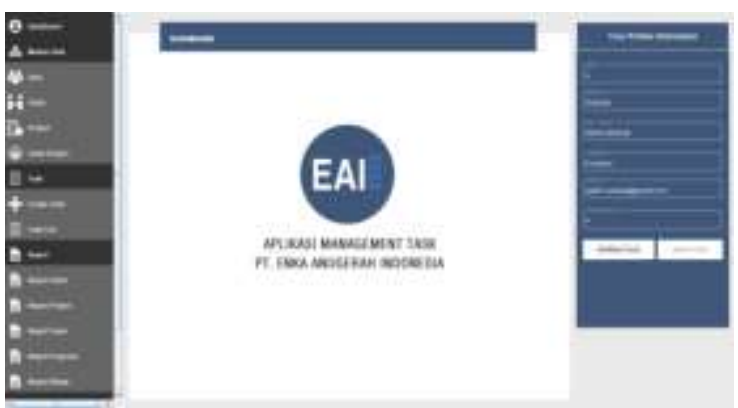

Gambar 4. Tampilan Menu Utama

Dimenu create task, user dapat memasukan data pada form yang telah disediakan. Setelah data masuk maka akan lanjut ke proses selanjutnya yaitu penambahan point task yang nantinya akan menjadi task yang akan di kerjakan oleh karyawan.
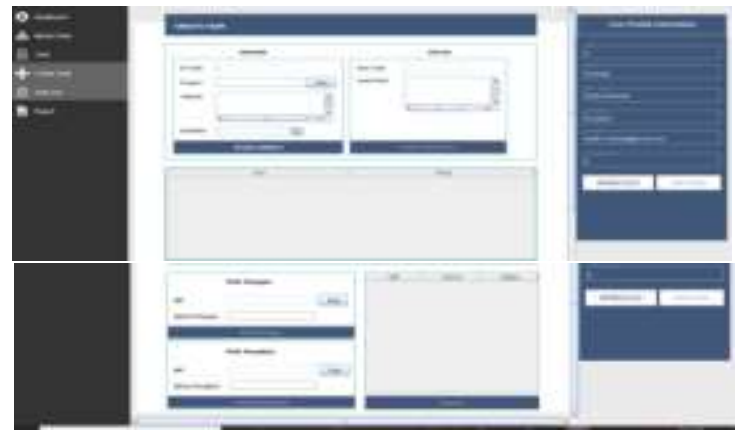

Gambar 5. Tampilan Menu Create Task 
Dimenu task list, user dapat menambahkan, merubah atau menghapus data task yang telah dibuat jika terjadi suatu kesalahan data.

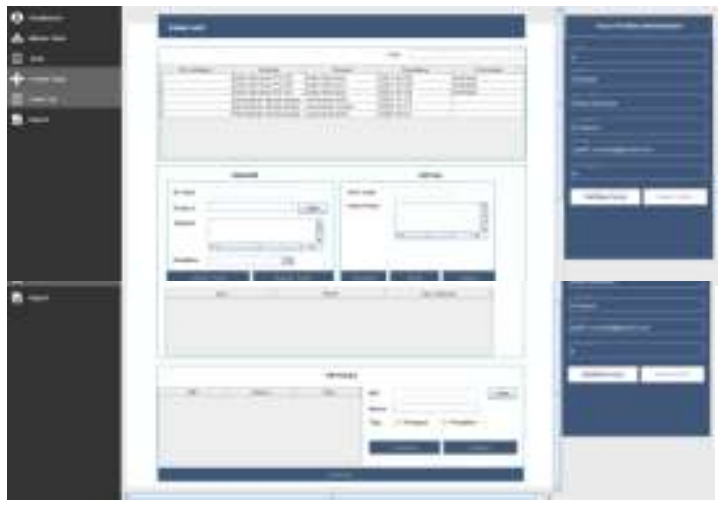

Gambar 6. Tampilan Menu Task List

Dimenu my task karyawan dapat update progress task yang dibebankan kepadanya, di menu ini nanti nya akan terlihat progress kerja yang sudah dilakukan oleh karyawan.
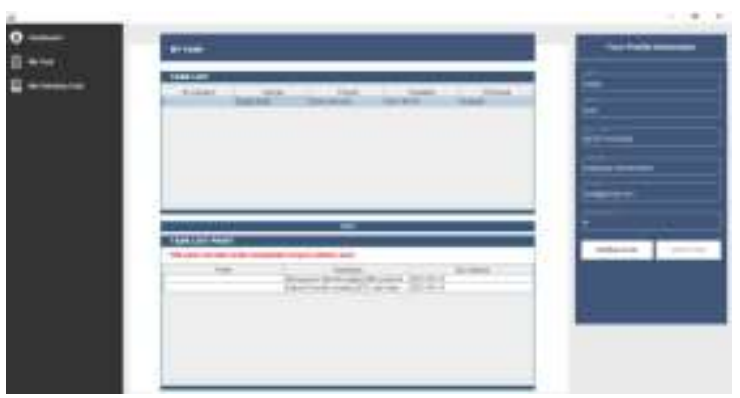

Gambar 7. Tampilan Menu My Task

Dimenu my following task, leader project dapat mengawasi progress kerja yang sedang di kerjakan oleh karyawan bawahannya.
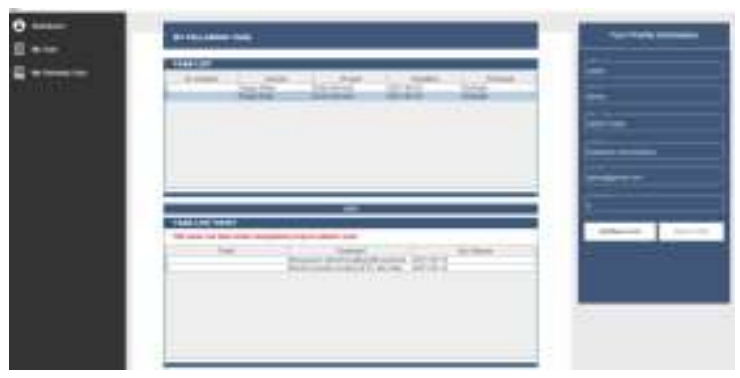

Gambar 8. Tampilan Menu My Following Task

Dihalaman menu laporan progress user dapat mengisi halaman filtering untuk mendapatkan laporan yang sesuai dengan keinginan, namun jika ingin menampilkan semua laporan progress maka filter tidak perlu disi. Selain itu, user juga dapat men download laporan.
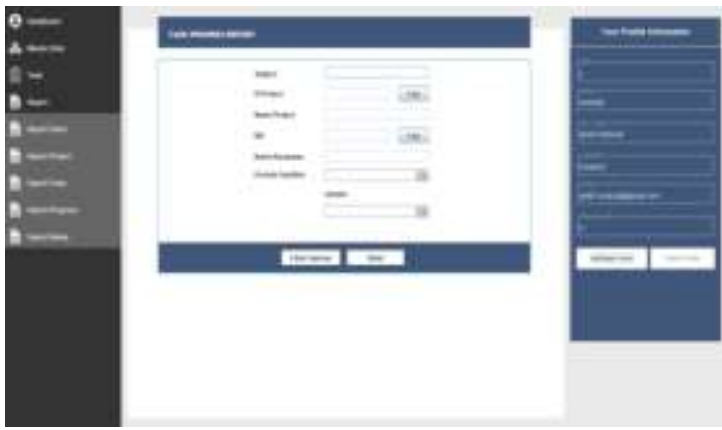

Gambar 9. Tampilan Menu Laporan Progress

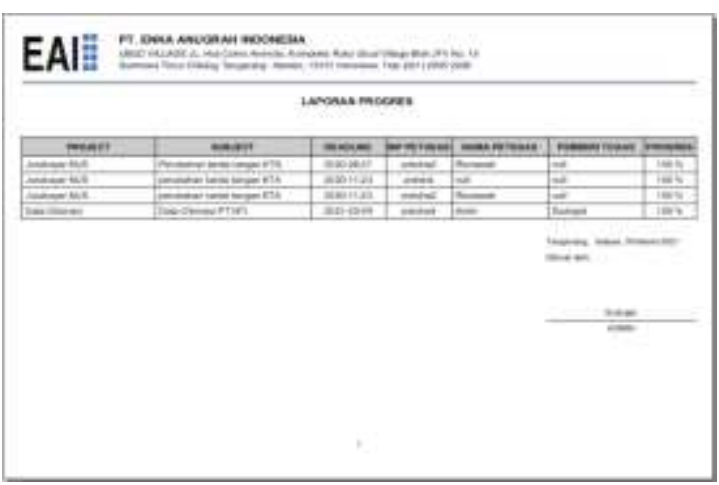

Gambar 10. Tampilan Hasil Laporan Progress

Dihalaman menu laporan rekap, user dapat mengisi halaman filtering untuk mendapatkan laporan yang sesuai dengan keinginan,namun jika ingin menanpilkan semua laporan rekap maka filter tidak perlu disi. Selain itu, user juga dapat men download laporan yang hasilnya akan tersimpan difolder download dari perangkat user berupa file pdf.

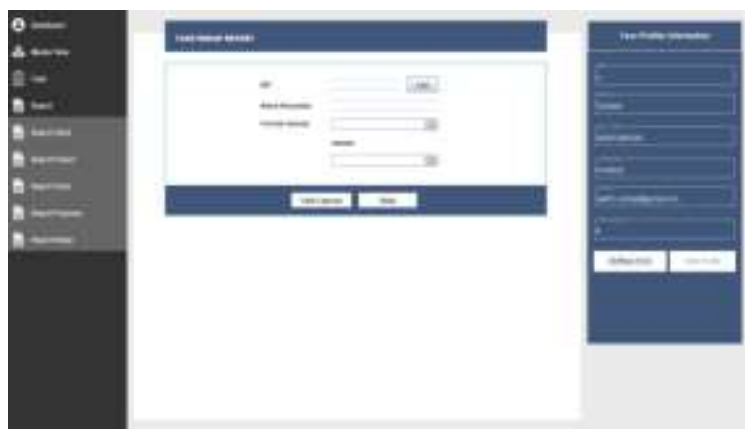

Gambar 11. Tampilan Menu Laporan Rekap 


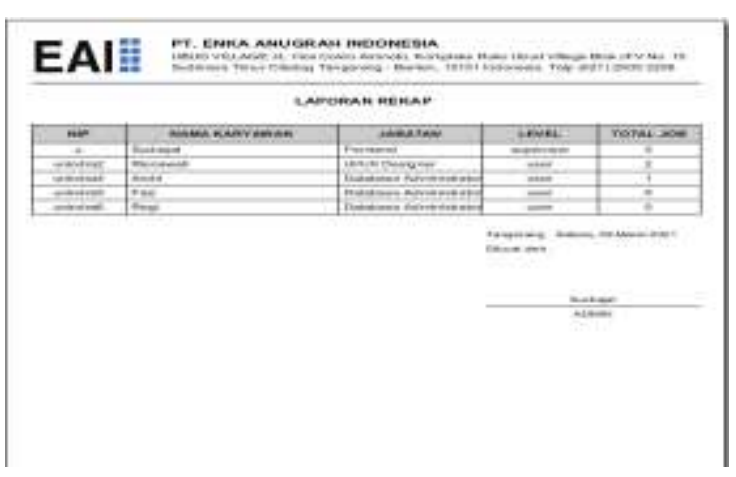

Gambar 12. Tampilan Hasil Laporan Rekap

Pada aplikasi management task ini, user pun dapat mengubah profile information, dengan cara mengaktifkan form nya kemudian isi fieldfield kemudian simpan, maka profile information yang baru akan terupdate.

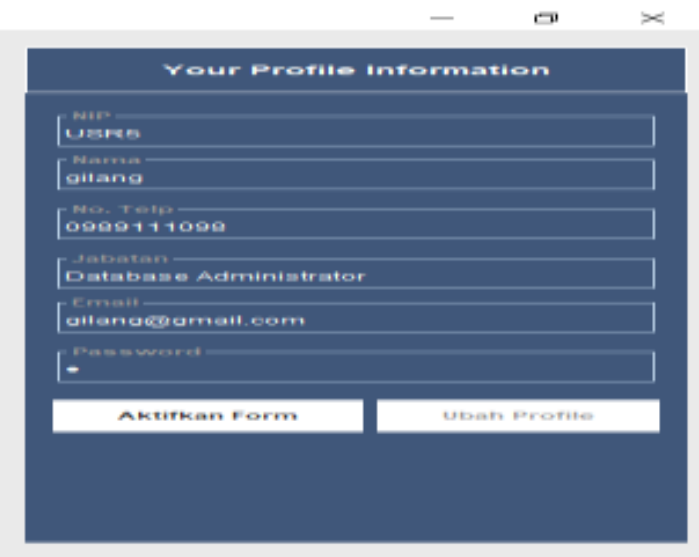

Gambar 13. Tampilan Layar ubah profil

\section{SIMPULAN DAN SARAN}

Berdasarkan uraian pada hasil dan pembahasan penelitian diatas, dapat disimpulkan bahwa aplikasi management task dapat mempermudah pendistribusian atau mengontrol setiap progress dari pekerjaan yang ditugaskan kepada karyawan dengan sangat efektif dan efisien. Kemudian mempermudah dan mempercepat leader project mengontrol progress tugas yang sedang dikerjakan oleh para karyawan dan mempermudah dalam membuat rekap atau laporan pekerjaan yang telah diselesaikan dalam satu periode.

Untuk menyempurnakan aplikasi management task, ada beberapa saran yang nantinya bisa dipergunakan sebagai masukan dalam mengembangkan aplikasi. Aplikasi ini sebaiknya dikembangkan agar bisa dipakai pada aplikasi berbasis web atau aplikasi android lainnya. Pada versi pertama ini, aplikasi belum mengimplementasikan logout, penulis berharap untuk versi selanjutnya dapat ditambahkan logout.

\section{DAFTAR PUSTAKA}

A. S, R., \& Shalahuddin, M. (2018). Rekayasa Perangkat Lunak Struktur dan Berorientasi Objek. Bandung: Bandung : Informatika.

Ahmad Subhan Roza, A. W. (2015). Teori Pembelajaran Bahasa - Google Books. Retrieved August 6, 2021, from https://www.google.co.id/books/edition/T eori_Pembelajaran_Bahasa/2HFcCwAA QBAJ?hl=id\&gbpv=1\&dq=apa+yang+di maksud+dengan+task\&pg=PA358\&print $\mathrm{sec}=$ frontcover

Aryanto. (2018). Soal Latihan dan Jawaban Pengolahan Database Mysql Tingkat Dasar / Pemula - Google Books. Retrieved June 20, 2021, from https://www.google.co.id/books/edition/S oal_Latihan_dan_Jawaban_Pengolahan_ Data/ZG9nDwAAQBAJ?hl=id\&gbpv $=1$ $\& \mathrm{dq}=$ pengertian+database $\& p g=P A 17 \& p r$ intsec $=$ frontcover

Bahrudin, R. M., Ridwan, M., \& Darmojo, H. S. (2019). Penerapan Helpdesk Ticketing System Dalam Penanganan Keluhan Penggunaan Sistem Informasi Berbasis Web. JUTIS, Vol.7 No.1.

Fauzan, R., \& Nugraha, I. B. (2017). Pembangunan Aplikasi Task Management Dalam Mendukung Proyek Pengembangan Perangkat Lunak (Studi Kasus: Pt. Ebdesk Indonesia). Jurnal Terapan Teknologi Informasi, 1(2), 131141.

https://doi.org/10.21460/jutei.2017.12.44

Hendini, A. (2016). Pemodelan Uml Sistem Informasi Monitoring Penjualan Dan Stok Barang. Jurnal Khatulistiwa Informatika, 2(9), 107-116. https://doi.org/10.1017/CBO9781107415 324.004

Karnovi, R. H. R. (2020). Tutorial membuat aplikasi sistem monitoring terhadap job desk operational h... - Google Books. Retrieved August 6, 2021, from https://www.google.co.id/books/edition/T utorial_membuat_aplikasi_sistem_monit or/g5LuDwAAQBAJ?hl=id\&gbpv $=1 \& \mathrm{dq}$ $=$ pengertian+aplikasi $\&$ pg $=$ PA14\&printse $\mathrm{c}=$ frontcover

Nofriandi. (2018). Java Fundamental dengan Netbeans 8.0.2 - Google Books. Retrieved 
June 20, 2021, from

https://www.google.co.id/books/edition/J

ava_Fundamental_dengan_Netbeans_8_0

_2/Lw1SDwAAQBAJ?hl=id\&gbpv=1\&d

$\mathrm{q}=$ netbeans+adalah\&pg $=\mathrm{PA} 5 \&$ printsec $=\mathrm{f}$ rontcover

Robby Saepul, R. H. N. (2019). Pengantar Manajemen - Google Books. Retrieved August 6, 2021, from https://www.google.co.id/books/edition/P engantar_Manajemen/ZjqnDwAAQBAJ? $\mathrm{hl}=\mathrm{id} \& \mathrm{gbpv}=1 \& \mathrm{dq}=$ manajemen + adalah $\&$ printsec $=$ frontcover

Zega, M. O., Chandrika, D., Siswanto, R., \& Supardinah, F. (2018). Aplikasi System Management Task Dan Penilaian Kerja (Kpi) Pada Pt Intisoft Mitra Sejahtera. ILKOM Jurnal Ilmiah, 10(3), 306-314. https://doi.org/10.33096/ilkom.v10i3.387. 306-314 